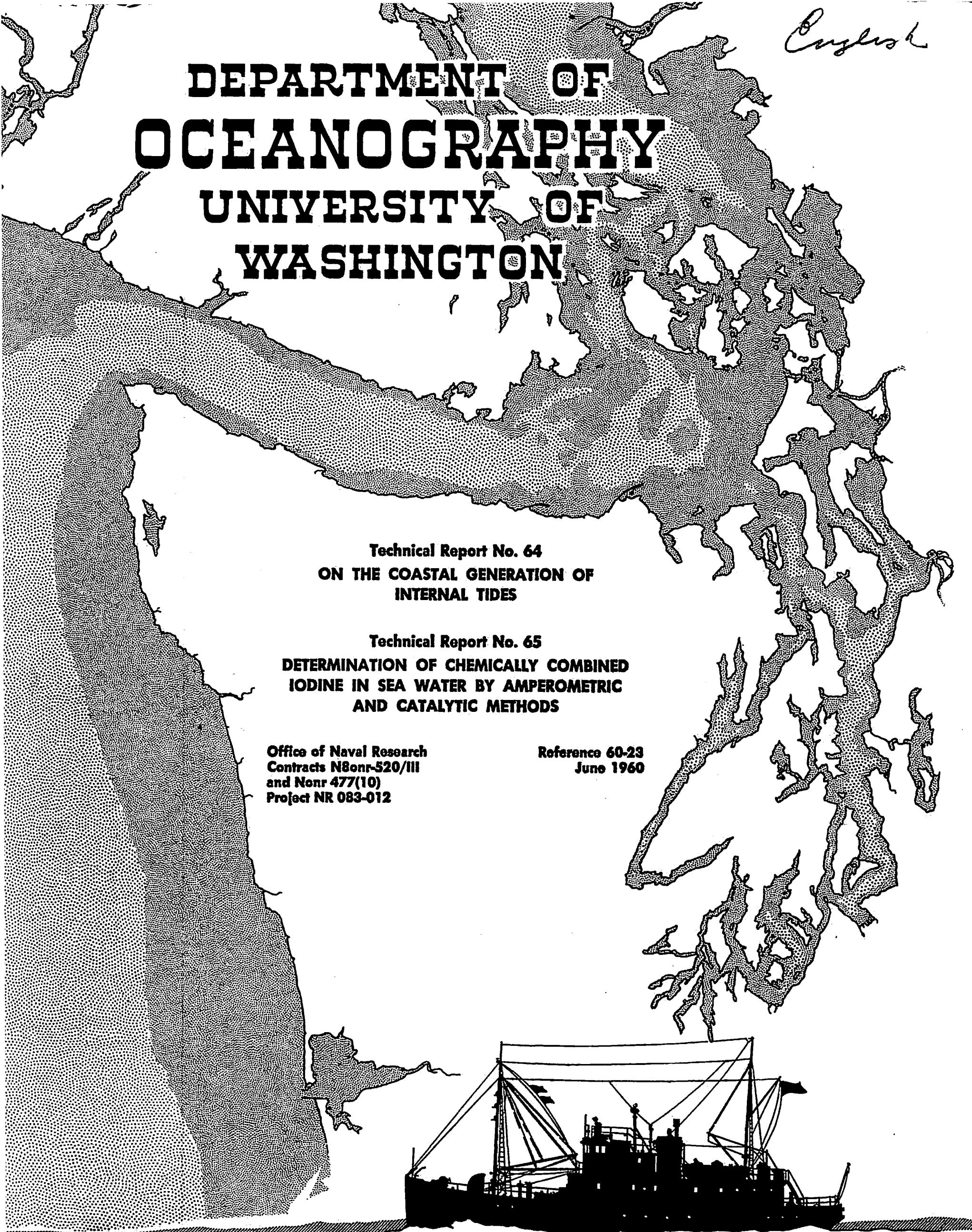




\section{UNIVERSITY OF WASHINGTON DEPARTMENT OF OCEANOGRAPHY Seattle 5, Washington}

Technical Report No. 64

ON THE COASTAL GENERATION OF INTERNAL TIDES

by

Maurice Rattray, Jr.

Technical Report No. 65

DETERMINATION OF CHEMICALIY COMBINED IODINE IN SEA WATER

BY AMPEROMETRIC AND CATALYTIC METHODS

by

Richard A. Barkley and Thomas G. Thompson

Office of Naval Research

Contracts N8onr-520/III

and Nonr 477(10)

Project NR 083-012

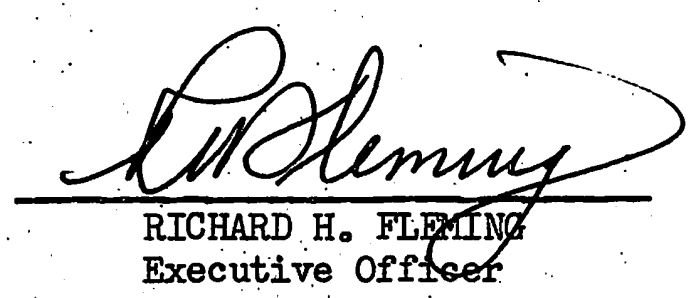

Reproduction in whole or in part is permitted for any purpose of the United States Government. 


\title{
Determination of Chemically Combined lodine in Sea Water by Amperometric and Catalytic Methods
}

\author{
RICHARD A. BARKLEY and THOMAS G. THOMPSON \\ Department of Oceanography, University of Washington, Seattle, Wash.
}

\begin{abstract}
lodine, in the form of iodides and iodates, exists in sea water in very small concentrations. In previous studies iodine has been concentrated from large samples by precipitation, extraction, or distillation. Using amperometric or catalytic methods the iodine may be determined directly on relatively small samples in much less time and with elimination of loss of iodine inherent in other methods. For extensive oceanographic studies the two methods may complement one another. The amperometric method permits ready determination of iodine in the form of iodate and iodide. The catalytic method permits determination of total iodine more rapidly and accurately than the amperometric method. The difference between the total iodine and the iodate-iodine gives the iodide-iodine. Some data are given for the distribution of iodine in the Northeast Pacific.
\end{abstract}

$\mathrm{T}$ wo methods for the determination of chemically combined iodine were examined for application to the analysis of sea water. The anperometric method permits direct titration of free or liberated iodine at extremely low concentrations by applying the very sensitive electrode system developed by Potter and White (11). The system responds to the presence of $10^{-11} M$ concentrations of elemental iodine. The catalytic method of Lang (10), later studied by Sandell and Kolthoff (12), utilizes the acceleration of the reaction between ceric sulfate and arsenous acid by iodine.

Investigations of the iodine content of sca water were begun soon after the discovery of the element by Courtois in 1812. Vinogradov (20) summarizes the results of analyses of oceanic iodine published up to 1933 . In 1932, Evans (b) reviewed the methods for iodine analysis used by previous investigators and reported his own findings for sea water from the Strait of Juan de Fuca. More recently, Sugawara and Terada (15) used silver nitrate to determine the iodide and total iodine content of a large number of samples from the Northwest Pacific, while Dubravicic (4) used the catalytic method to analyze sea water from the Adriatic. Although the results of the investigations since 1916 vary from about $10 \gamma$ per liter of iodine to slightly less than $100 \gamma$ per liter, most of the values range between 40 and 60 $\gamma$ per liter, with Sugawara and 'Terada's values (which are the most numerous), averaging about $43 \gamma$ per liter. Dubravicic (4) found $63 \gamma$ per liter in a surface sample from the Adriatic.

Prior to the development of the catalytic method for the determination of iodine, no method was sensitive enough to permit a direct determination of the element in sea water. Iodine was concentrated by precipitation, extraction, or distillation from relatively large samples and final estimation was done cither colorimetrically or volumetrically.

Before Sugawara and Terada (15) presented their extensive data on iodide and iodate, few attempts had been made to determine the forms of iodine present in the oceans. Winkler (21) reported the inorganic iodine in the waters of the Adriatic as $9 \gamma$ per liter of iodide and $41 \gamma$ per liter of iodate; no iodine was found in organic combination. Cameron (3) found $2.5 \gamma$ per liter of iodide and $22.5 \gamma$ per liter of iodate in surface water of the Strait of Georgia, British Columbia. Sugawara and Terada (15) determined iodide and total iodine by precipitation as silver iodide. The iodide content of their samples varied from about 10 to $100 \%$ of the total iodine. They considered the noniodide iodine in their samples to be iodate.

Shaw and Cooper (18) suggested that the iodate thus reported was, in fact, hypoiodous acid, as the reaction by which iodate would be formed in sea water is trimolecular and could be expected to proceed at a very low rate; they pointed out, however, that iodate would be the thermodynamically stable form of iodine in the oceuns. Despite the empirical data presented in rebuttal by Sugawara and Terada (16) and by Johannesson (9), Shaw and Cooper (14) consider that many of the questions which they raised remain unanswered, although they agree that iodate appears to be the oxidized form of iodine in the sea.

\section{THE AMPEROMETRIC METHOD}

The amperometric method of Potter and White (11) was used for the determination of traces of iodine in sea water. A potential of about 0.3 volt applied across two platinum electrodes causes a current to flow through the circuit. The current changes abruptly at the end point of the iodine-thiosulfate titration. In place of a galvanometer, which is normally used, Potter and White placed a resistor in series with the electrodes and measured the change in potential across the resistor. By using a vacuum-tube voltmeter capable of detecting a change in potential of $1 \mathrm{mv}$., together with a 50-megohm resistor, changes in current flow through the circuit of $10^{-11}$ ampere could be detected. Thus, the circuit provides a sensitivity some three orders of magnitude greater than that normally attained in amperometric titrations using a galvanometer and permits the direct titration of the $5 \times 10^{-7} M$ concentrations of iodine present in sea water. The electrode response near the end point was approximately $4 \times 10^{-11}$ ampere for each change of $1 \times 10^{-11}$ mole of free iodine in the solution, or a measurable change of $2 \mathrm{mv}$. for each $1 \times 10^{-11}$ mole change in iodine concentration.

The determination was performed by allowing iodate in the acidificd sample to react with excess iodide, liberating 6 equivalents of iodine for each equivalent of iodate originally present. A known excess amount of thiosulfate was then added and the excess was determined by back-titration with standard iodate solution. The iodate content of sea water could be determined directly, while the total iodine content was determined by first oxidizing all the iodine to iodate by means of bromine. Thus, using two aliquots of the same sample, iodine in the form of iodate and total inorganic iodine could be readily determined.

\section{DETERMINATION OF IODATE IN SEA WATER}

Apparatus. Figure 1 shows the arrangement of the apparatus together with the electrode assembly. The electrodes consisted of short lengths of platinum wire sealed into glass tubing with $1 \mathrm{~cm}$. of wire exposed. The resistors were of ordinary commercial manufacture, with tolerances of $10 \%$ of the nominal value. 


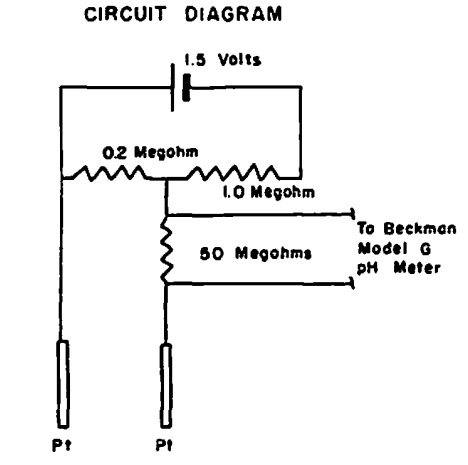

Figure 1. Circuit diagram and arrangement used for amperometric titration

To protect the assembly against moisture, the resistors were wrapped with insulating tape and the leads from the electrodes to the resistors were enclosed in flexible plastic tubing whose ends were also wrapped with tape. The required voltage was supplied by an ordinary dry cell. The dry cell was replaced every 2 or 3 months as a precautionary measure. Potentiometric measurements were made with a Beckman Model G pH meter. A 1-ml. air-controlled microburet, which delivered $0.005-\mathrm{ml}$. increments, was made and calibrated as described by Upson (19).

Reagents. Sodium Thiosulfate. A $0.1 N$ stock solution was prepared by dissolving 25 grams of the pentahydrate salt in 1 liter of freshly boiled distilled water. About $1 \mathrm{ml}$. of carbon disulfide was added as a preservative. A $0.0002 N$ working solution was prepared daily, first by diluting $10 \mathrm{ml}$. of the stock solution to exactly $100 \mathrm{ml}$. with freshly boiled distilled water, and then by diluting $20 \mathrm{ml}$. of the resulting solution to exactly $100 \mathrm{ml}$.

Standard Iodate Solution. A $0.0500 \mathrm{~N}$ stock solution was prepared by dissolving 1.9496 grams of potassium acid iodate in exactly 1 liter of water. A working solution, $0.000500 N$, was prepared by successive dilutions.

ACETIC ACID. $125 \%$ solution was made by diluting $250 \mathrm{ml}$. of glacial acetic acid to 1 liter.

NITrogen. Water-pumped tank nitrogen was bubbled through pyrogallol and distilled water, and then into the apparatus to remove oxygen from the solution to be titrated.

Potassium Iodide. Iodate-free reagent grade crystals were used directly to provide the required excess of iodide for titration.

Procedure. A $100-\mathrm{ml}$. sample of sea water was placed in a 125-ml. Erlenmeyer flask and acidified by the addition of $10 \mathrm{ml}$. of $25 \%$ acetic acid. Dissolved oxygen was removed by passing nitrogen through the solution for 15 minutes. Then $1 \mathrm{ml}$. of $0.0002 \mathrm{~N}$ thiosulfate solution was added, followed by two or three crystals of potassium iodide. With the electrodes in position, the titration was performed by adding increments of iodate solution until the potentiometer needle showed a deflection; thereafter,

TITRATION ASSEMBLY

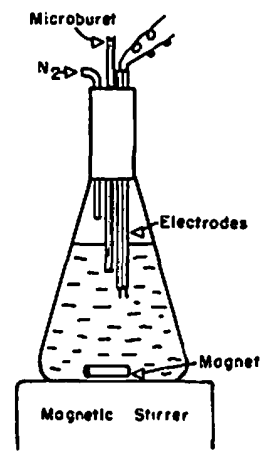

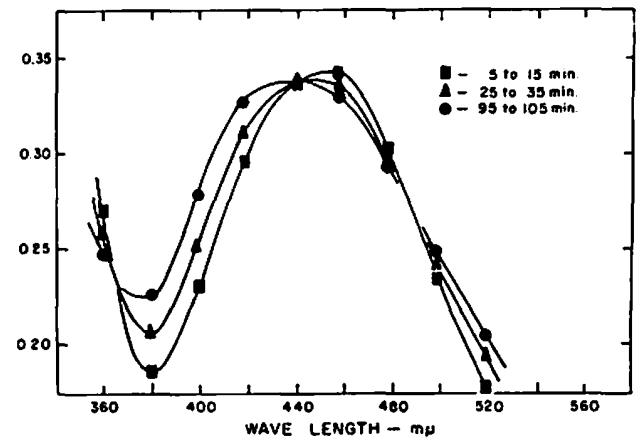

Figure 2. Brucine spectrum with time variation

small increments were added, with careful measurement of the potential 30 seconds after each addition. The end point was located by plotting potential against volume added, the intercept of the pre- and the post-end point curves being taken as the required volume for titration.

The volume of iodate solution used in titrating the unknown sample, subtracted from the volume required to titrate the same volume of thiosulfate in a blank determination, was the iodate equivalent of the sample.

In adjusting the $\mathrm{pH}$ meter for the titration, the bridge was rebalanced each time the potential changed significantly to prevent disturbance in the electrode circuit by the unbalanced bridge. The resistance of the potentiometer must be higher than that in the electrode circuit, otherwise the meter will act as a shunt and the results will be meaningless.

Prior to initial use, the electrodes were pretreated as suggested by Potter and White (11) and needed no further attention. The electrodes were always kept immersed. Between titrations, the electrodes were simply rinsed with distilled water.

Standardization. The reagents used in the titration were standardized against each other at each step in the dilution of the stock solutions to the working concentration, with the stock acid iodate as the original standard.

In the standardization of the $0.0002 N$ thiosulfate solution in nine determinations, $1 \mathrm{ml}$. of the solution in redistilled water required a mean of $0.349 \mathrm{ml}$. of standard iodate solution, the minimum value being $0.344 \mathrm{ml}$. and the maximum $0.360 \mathrm{ml}$. The standard deviation was $0.012 \mathrm{ml}$.

\section{DETERMINATION OF TOTAL IODINE IN SEA WATER}

The apparatus used is the same as described previously.

Reagents. In addition to the reagents and standards listed above, reagent grade bromine was purified by shaking with potassium bromide and distilling in an all-glass apparatus.

Procedure. A $100-\mathrm{ml}$. sample of sea water was placed in a $125-\mathrm{ml}$. Erlenmeyer flask and acidified by the addition of $10 \mathrm{ml}$. of $25 \%$ acetic acid.
Table I. Recovery of Added lodide by the Amperometric Method

$\begin{array}{ccc}\begin{array}{c}\text { Iodine } \\ \text { Added, }\end{array} & \begin{array}{c}\text { Iodine } \\ \text { Found, }\end{array} & \begin{array}{c}\text { Error, } \\ \gamma\end{array} \\ \gamma & \gamma & +0.54 \\ 0.00 & 0.54 & +0.04 \\ 2.00 & 1.96 & -0.04 \\ 4.00 & 3.96 & +0.05 \\ 6.00 & 6.05 & +0.09 \\ 8.00 & 8.09 & 0.00 \\ 10.00 & 10.00 & +0.06 \\ 0.20 & 0.26 & +0.01 \\ 0.50 & 0.49 & +0.12 \\ 1.00 & 1.12 & +0.57 \\ 0.00 & 0.57 & \end{array}$

Bromine vapor was then poured into the flask (with swirling to mix the vapor with the sample) until the latter had a distinct coloration. The sample was evaporated on a water bath to one half the original volume to remove excess bromine completely, then the sample was diluted to $100 \mathrm{ml}$. with distilled water, and the titration was conducted as described above.

In oxidizing the sample with bromine, the $\mathrm{pH}$ of the solution should not be less than about pH 2, as Evans ( $)$ has shown that the reaction is reversible in strongly acid solutions and that elemental iodine is lost when the sample is heated too vigorously to remove excess bromine.

Ten determinations for total iodine were run on the same sample of sea water, which had a chlorinity of $16.82 \%$. The mean value for total iodine was $48.3 \gamma$ per liter, the minimum result being $45.5 \gamma$ per liter and the maximum $51.0 \gamma$ per liter. The standard deviation was $2.1 \gamma$ per liter.

To test the procedure for total iodine, known amounts of iodide were added to redistilled water and the solutions were analyzed. The results (Table I) indicate that the error of the determination is almost constant in the range 0.5 to $10 \gamma$ in $100-\mathrm{ml}$. samples.

\section{THE CATALYTIC METHOD}

Browning and Cutler (2) showed the rate of reaction between the arsenous and ceric ions to be exceedingly small. Feigl (6) postulated a mechanism for the iodine-catalyzed reaction. Reaction rates have been measured in various ways for the determination of iodine $(7,8,12)$. The effects of chloride on 


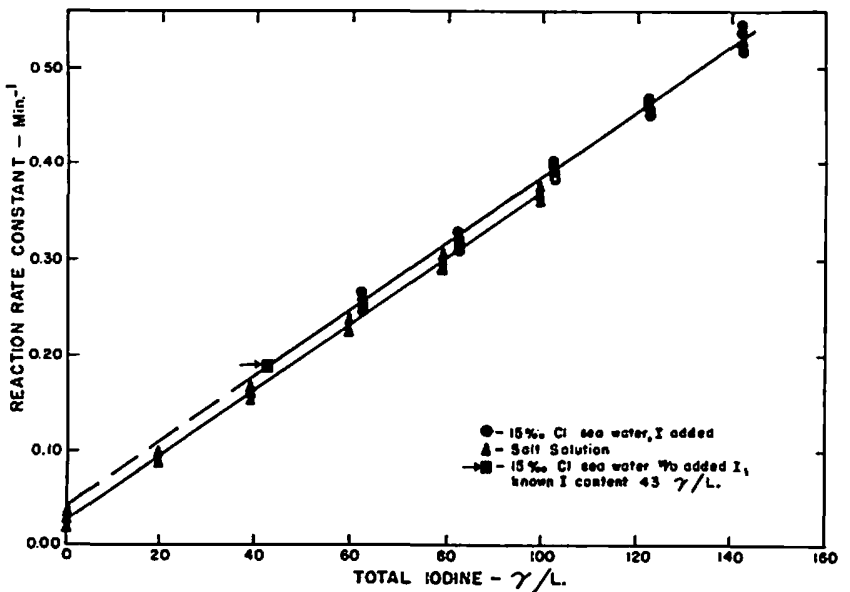

Figure 3. Reaction rate constant vs. total iodine content

the determination of iodine were discussed by Dubravicic (4).

The reaction rate is a function of the concentrations of iodine, ceric ion, and arsenous acid. Iodine, however, does not vary in concentration in any one sample, because it acts as a catalyst. Arsenous acid is added in large excess of the amount required to react with the ceric sulfate so that the changes in arsenous acid concentration during the course of the reaction are negligible. Under thcse circumstances the reaction appears to proceed with first-order kinetics, which obey the integral equation:

$$
k=\frac{2.303}{t_{2}-t_{1}} \log \frac{[\mathrm{CeIV}]_{1}}{[\mathrm{CeIV}]_{2}}
$$

The first-order reaction rate constant, $k$, can be computed by measuring the ceric ion concentrations at various times during the reaction. The rate constant, in turn, can be empirically related to the iodine concentration in the sample.

Brucine was the most satisfactory reagent for measuring the ceric ion concentration. It reacted instantly with any remaining ccric ion to quench the catalytic reaction and at the same time produced a coloration which was directly proportional to the ceric ion concentration. The color was stable for 2 hours or more. Figure 2 shows the spectrum of the brucine coloration and its changes with time. The maximum absorption occurs initially near $460 \mathrm{~m} \mu$, shifts to about $450 \mathrm{~m} \mu$, and finally to about $440 \mathrm{~m} \mu$ after 30 and 100 minutes, respectively. A region near $440 \mathrm{~m} \mu$ shows little change in absorption with time and this wave length was thus chosen for measurements. The effect of temperature upon absorptivity between $17^{\circ}$ and $32^{\circ} \mathrm{C}$. was negligible.

Osmium, iodine, and bromine $(1,12)$ act as catalysts, with osnium being the most active and bromine the least. To ensure the presence of constant concentrations of bromide in the samples of sca water $(17,18)$ as well as of other ions in sea water which occur in constant proportions, the samples were always diluted to the same chlorinity. Sea water which had been treated with silver nitrate to remove the halides showed no catalytic activity.

\section{DETERMINATION OF TOTAL IODINE IN SEA WATER}

Apparatus. A Beckman Model DU spectrophotometer with $1-\mathrm{cm}$. glass cells was used to measure the absorptivity. An 80-liter water bath with stirrer and heater, maintained at $30.00^{\circ} \pm 0.05^{\circ} \mathrm{C}$., was used to control reaction temperature. The reaction vessels were $32 \times 160 \mathrm{~mm}$. test tubes which were fitted into holes in a sheet of foamed polystyrene floated in the water bath. The ceric reagent was supported inside the bath to keep it at the required temperature. Aliquot portions of the reaction mixtures were removed from the test tube with a 5-ml. dispenser manufactured by the California Laboratory Supply Co. These T-shaped dispensers were attached to the mouth of each test tube reaction vessel, filled by rotating the assembly through an angle of $90^{\circ}$, and emptied by returning the assembly to the vertical position. The dispensers delivered volumes reproducible within $1 \%$.

Reagents. Arsenous AcId. First, 19.8 grams of reagent grade arsenic trioxide were dissolved in $200 \mathrm{ml}$. of warm distilled water containing 8.0 grams of sodium hydroxide; then the solution was diluted to about 800 ml., acidified with $94 \mathrm{ml}$. of $18 \mathrm{~N}$ sulfuric acid, and, after cooling, diluted to 1 liter.

Sulfatoceric Acid. A $0.016 \mathrm{~N}$ solution in $1.5 \mathrm{~N}$ sulfuric acid was prepared by dissolving 10.1 grams of reagent grade ceric ammonium sulfate dihydrate in $200 \mathrm{ml}$. of distilled water to which had been added $41.4 \mathrm{ml}$. of $36 \mathrm{~N}$ sulfuric acid. The solution was diluted to 1 liter, allowed to stand for 3 days, and then filtered through a Millipore filter.

Brucine Reagent. Exactly 2.5 grams of brucine were dissolved in $500 \mathrm{ml}$. of distilled water containing $14 \mathrm{ml}$. of $36 \mathrm{~N}$ sulfuric acid. This solution must be kept in brown glass bottles, where it remains usable for 2 to 3 weeks.

Procedure. The samples of sea water were filtered through a Millipore filter, their chlorinities were determined, and $25 \mathrm{ml}$. of each sample were diluted with redistilled water to give a chlorinity of $15 \% ; 25 \mathrm{ml}$. of the diluted sample were placed in a large test tube, $20 \mathrm{ml}$. of the arsenous acid reagent were added, and the solutions were thoroughly mixed. The test tubes were then placed in the water bath for $\mathbf{3 0}$ minutes.

The reaction was initiated by adding $5 \mathrm{ml}$. of the ceric reagent, mixing as rapidly as possible, and replacing the reaction vessel in the water bath. A stop watch was started just as the ceric reagent was added. Subsequently, a minimum of four 5-ml. aliquots of the reaction mixture were removed at predetermined intervals and quenched by pouring each into a small test tube containing $1 \mathrm{ml}$. of brucine reagent. The aliquots were taken by starting to fill the attached dispenser 10 seconds before the scheduled time, emptying the aliquot into brucine at exactly the time desired, and allowing 10 seconds for reproducible drainage of the dispenser. Normally, aliquots were taken every 2 minutes until four had been quenched.

The absorptivities of the quenched aliquots were then measured (in the same order in which they were taken) in the spectrophotometer at $440 \mathrm{~m} \mu$, with a slit width of $0.04 \mathrm{~mm}$. and a distilled water comparison cell. After the reaction had gone to essential completion and no ceric ion coloration remained in the mixture, $a$ fffth aliquiot was removed which, when quenched with brucine, was measured in the spectrophotometer; the reading thus obtained was subtracted from the readings obtained with the previous aliquots as a reagent blank correction.

The corrected absorptivities of the quenched aliquot portions were substituted into the first-order reaction rate constant equation to obtain a numerical estimate of the reaction rate constant of the sample. The absorptivities of the 1- and 5-minute aliquots and the 2- and 6-minute aliquots were used separately to obtain two individual values for the rate constant of one sample. Where the two rate constants differed by more than $5 \%$, the absorptivities were plotted against time on 
semilog graph paper, the best fit line was drawn through any three of the four points, and the rate constant was calculated graphically.

Calibration. Known amounts of iodine were added to sea water, which had been diluted to $15 \%$ obtain a calibration curve of reaction rate against iodine content (Figure 3 ). As a check on the linearity of the calibration curve at iodine contents below that of the sea water used for calibration, an artificial iodine-free sea water was prepared from purified salts and adjusted to $15 \% \mathrm{Cl}$; then various known amounts of iodine were added. This curve is also shown in Figure 3. Both curves were straight and parallel, justifying the extrapolation of the sea water calibration curve in the direction of lower iodine concentrations. Bromide was added to artificial, iodinefree sea water to produce another calibration curve.

A least-squares treatment of all the calibration data resulted in the following linear equation, applicable to sea water diluted to $15 \% \mathrm{Cl}$, with the reagents and methods given above:

$$
\begin{array}{rl}
k=0.013 & \mathrm{~min} .^{-1}+3.6 \times 10^{-1} \\
\frac{\mathrm{min} .^{-1}}{\mathrm{mg} \cdot \mathrm{Br} / \mathrm{liter}} & +3.70 \frac{\mathrm{min} .^{-1}}{\mathrm{mg} . \text { I/liter }}
\end{array}
$$

where the term $0.013 \mathrm{~min}^{-1}$ was the rate constant due to the reagents in either redistilled water or artificial sea water. The bromide term in the equation can be considered a constant, 0.019 min..$^{-1}$, because the $\mathrm{Br} / \mathrm{Cl}$ ratio for sea water was shown to be constant by Thompson and Karpi (18). Their data showed a mean value for the ratio $\mathrm{Br} / \mathrm{Cl}$ of 0.00347 with a range of 0.00344 to 0.0351 , so that $52 \mathrm{mg}$. per liter of bromide should be present in $15 \% \mathrm{Cl}$ sea water. This amount of bromide has a catalytic effect equivalent to the effect of $0.005 \mathrm{mg}$. I per liter ( $5 \gamma$ pcr liter), so that even $100 \%$ variation in the bromide concentration would produce an error in the iodine determination in sea water of only $10 \%$. The equation for computing the iodine concentration from a determination of the rate constant is therefore:

$$
\begin{aligned}
& \mathrm{I}(\gamma / \text { liter })=\frac{k-0.032}{3.70} \times 10^{3}= \\
& \frac{10^{3} k}{3.70}-8.6
\end{aligned}
$$

As an additional check on the validity of the calibration, the iodine content of the sea water used for calibration was determined by means of the amperometric method; an iodine value of 48.3 $\boldsymbol{\gamma}$ per liter was obtained for the original sample at $16.82 \% \mathrm{Cl}$, so that $43 \gamma$ per liter were present in the sample when diluted to $15 \% \mathrm{Cl}$. This value

Table II. lodine Determinations by the Amperometric and Catalytic Methods

$$
\begin{aligned}
& \text { Total Inorganic } \\
& \text { Iodine Found, } \\
& \begin{array}{ccc}
\text { Nominal } & \frac{\gamma / \text { Liter }}{\text { Depth, }} & \text { Chlorinity, Catalytic } \\
\text { Meters } & \begin{array}{c}
\text { Ampero- } \\
\text { metric }
\end{array} & \begin{array}{c}
\text { Difference, } \\
\gamma / \text { Liter }
\end{array}
\end{array}
\end{aligned}
$$

Station A

$52^{\circ} 06^{\prime} \mathrm{N}, 167^{\circ} 39^{\prime} \mathrm{W}$, Aug. 2, 1957

$\begin{array}{rrrrr}0 & 18.06 & \mathbf{5 8} & \mathbf{5 7 . 8} & 0.2 \\ 10 & \mathbf{1 8 . 0 6} & \mathbf{6 1} & \mathbf{5 8 . 6} & \mathbf{2 . 4} \\ \mathbf{2 5} & \mathbf{1 8 . 0 6} & \mathbf{5 8} & \mathbf{5 6 . 0} & \mathbf{2 . 0} \\ 40 & 18.07 & \mathbf{5 8} & \mathbf{5 4 . 9} & \mathbf{3 . 1} \\ 80 & \mathbf{1 8 . 1 8} & \mathbf{5 9} & \mathbf{6 3 . 5} & -4.5 \\ 120 & 18.50 & \mathbf{5 9} & \mathbf{5 8 . 5} & \mathbf{0 . 5} \\ 175 & \mathbf{1 8 . 7 5} & \mathbf{6 5} & \mathbf{6 1 . 0} & \mathbf{4 . 0} \\ 300 & 18.84 & \mathbf{6 5} & \mathbf{6 7 . 8} & -\mathbf{2 . 8} \\ 400 & 18.90 & \mathbf{6 7} & 63.0 & 4.0 \\ 600 & 18.98 & 62 & 64.5 & -\mathbf{2 . 5} \\ 800 & 19.02 & 64 & \mathbf{6 5 . 0} & -1.0 \\ 1000 & 19.04 & 64 & \mathbf{6 3 . 2} & 0.8 \\ 1200 & 19.08 & \mathbf{6 5} & \mathbf{6 6 . 0} & -1.0 \\ 1800 & \mathbf{1 9 . 1 4} & \mathbf{6 1} & \mathbf{5 8 . 8} & \mathbf{2 . 2}\end{array}$

Station B

$48^{\circ} 35^{\prime} \mathrm{N}, 122^{\circ} 51^{\prime} \mathrm{W}$, May 25 , 1957

$\begin{array}{rrrrr}5 & 14.97 & 41 & 39.0 & 2.0 \\ 20 & 16.49 & 46 & 48.5 & -2.5 \\ 45 & 16.91 & 47 & 46.7 & 0.3\end{array}$

Table III. Total lodine and lodate lodine Found in Sea-Water Samples

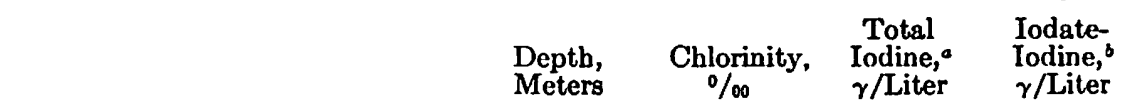

Station A

$52^{\circ} 06^{\prime} \mathrm{N}, 167^{\circ} 39^{\prime} \mathrm{W}$, Aug. 2, 1957

$\begin{array}{rr}60 & 18.10 \\ 100 & 18.30 \\ 150 & 18.68 \\ 200 & 18.77 \\ 300 & 18.86 \\ 500 & 18.94 \\ 700 & 19.00 \\ 900 & 19.04 \\ 1100 & 19.07\end{array}$

\section{7}

$57-30$.

58

58

63

63

63

65

62

30.2
25.6
28.0
32.5
26.0
29.7
21.4
27.0
30.3

Station B

$48^{\circ} 35^{\prime} \mathrm{N}, 122^{\circ} 51^{\prime} \mathrm{W}$, May 25,1957

10
30

15.92

42

42

20.5

- Catalytic determination.

- Amperometric determination.

agrees with that obtained in the catalytic procedure.

Iodide, elemental iodine, iodate, and periodate produced identical results with the method as given, where the sample was allowed to react with the arsenous acid for 30 minutes before the reaction was initiated. If, however, the ceric and arsenous reagents were added together or the ceric reagent was added first, iodate failed to catalyze the reaction for the first few minutes, after which the reaction rate began to increase until finally the reuction rate constant g.pproached the value to be expected for the iodine present in the sample. This suggests that iodate per se does not act as a catalyst but must first be reduced to a lower oxidation state by reaction with arsenous acid.

Figure 4 shows the progress of a typical catalytic reaction in sea water. The rapid initial removal of ceric ion was always observed but varied in extent from sample to sample and was attributed to the removal of ceric ion by small amounts of interfering material of unknown composition. After about 30 seconds the reaction proceeds with apparent first-order kinetics at a rate dependent only on iodine concentration when the other variables are controlled. Using the initial ceric ion concentration and only one subsequent point on the curve produces an erroneous value for the reaction rate constant. Thus, the first aliquot of the reaction mixture was not removed until 1 minute ufter the reaction had been initiated. The 4minute sampling interval used in computations was chosen to ensure a minimum of error, because this is the approximate time required in most samples for the ceric ion concentration to decrease by two thirds.

\section{RESULTS}

The amperometric method was usable in the determination of iodine in sea water in concentrations down to $5 \gamma$ per liter, with a standard deviation of 
$2.1 \gamma$ per liter. The determination of iodate in sea water samples could be performed directly, thus minimizing the chances of iodine loss or contamination of the sample. Ferric and cupric ions in concentrations up to $280 \gamma$ iron per liter and $320 \gamma$ copper per liter ( $5 \gamma$ atoms per liter in each case) do not interfere. The determination of the total iodine content of sea water samples could also be done amperometrically, but the preliminary oxidation of the sample with bromine is time-consuming and introduces the possibility of contamination or iodine loss. However, the standard deviation of the total iodine determination was found to be the same as that for the iodate determination, and the values obtained agreed well with those from the catalytic method. The principal contribution of the amperometric method is that it provides a rapid means for determining the form in which iodine occurs in sea water samples.

The catalytic method for the determination of iodine in sea water was usable for minimum iodine concentrations of about $5 \gamma$ per liter, with a standard deviation of $1.3 \gamma$ per liter. The determination is direct, with no interferences present in sea water except the other halides, whose concentrations can be easily controlled. It is the most direct and rapid method for total inorganic iodine determinations in the range of concentrations encountered in sea water samples.

The catalytic and the amperometric methods for iodate and total iodine were checked for accuracy from time to time during determinations on sea water samples by adding internal standards to duplicates of samples which had already been analyzed. Iodate or iodide standards were added at random but in fixed amounts which increased the concentrations by $40 \gamma$ per liter. For the amperometric determinations, the error was less than two standard deviations on over $90 \%$ of the determinations; for the catalytic determinations the error was greater but within three standard deviaations for $90 \%$ of the samples. The increased error in the catalytic method was attributed to the marked increase in reaction rate, which made measurement difficult.

Table II gives results obtained by the two methods in total iodine on samples of sea water from various depths at two stations, one in the northeast Pacific Ocean and the other in an embayment north of Puget Sound. Table III shows data obtained on samples from the same stations analyzed for total chemically combined iodine and for the iodine in the form of iodate.

\section{LITERATURE CITED}

(1) Anderson, R. C., Lasater, J. A., Lippman, D., J. Am. Chem. Soc. 71, 2577-8 (1949).

(2) Browning, P. B., Cutler, W. D., Z anorg. Chem. 22, 303-5 (1900).

(3) Cameron, A. T., Contribs. Can. Biol. and Fisheries 1, 75-80 (1922).

(4) Dubravicic, M., Analyst 80, 295-300 (1955).

(5) Evans, Lacey H., Ph.D. dissertation, Chemistry Department, University of
Washington, Seattle, Wash., pp. 38-86, 1932.

(6) Feigl, F., "Chemistry of Specific, Selective, and Sensitive Reactions," Academic Press, New York, 1949.

(7) Grossman, A., Grossman, G. F., J. Clin. Endocrinol. and Melabolism 15, 354-61 (1955).

(8) Hahn, F. L., Adler, M., Proc. Am. Sci. Congr., 7, 1942, 169-175, 8th Congr., Wash., D. C., Department of State, Washington, D. C.

(9) Johannesson, J. K., Nature 182, 251 (1958).

(10) Lang, R., Z. anal. u. allgem. Chem. 152,206 (1926).

(11) Potter, E. C., White, J. F., J. Appl. Chem. (London) 7, 309-28 (1957).

(12) Sandell, E. B., Kolthoff, I. M., J. Am. Chem. Soc. 56, 1426 (1934).

(13) Shaw, T. I., Cooper, L. H. N., Nalure 180, 250 (1957)

(14) Ibid., 182, 252 (1958).

(15) Sugawara, K., Terada, K., J. Earth Sci. Nagoya Univ. 5, 81-102 (1957).

(16) Sugawara, K., Terada, K., Nature 182,250 (1958).

(17) Sverdrup, H. U., Fleming, R. H., Johnson, M. W., "The Oceans," Prentice-Hall, New York, 1942.

(18) Thompson, T. G., Karpi, E., $J$. Marine Research 5, 28-36 (1942).

(19) Upson, U. L., Anal. Chem. 25, 977-9 (1953).

(20) Vinogradov, A. P. "The Elementary Chemical Composition of Marine Organisms," Memoir No. II, p. 647, Sears Foundation for Marine Research, Yale University, New Haven, Conn., 1953.

(21) Winkler, L. W., Z. angew. Chem. 29, 205-7 (1916).

RECEIVED for review July 21, 1959. Accepted October 30, 1959. Contribution No. 233 from the Department of Oceanography, University of Washington, Seattle, Wash. Research supported in part by the National Science Foundation and the Office of Naval Research, Contract 477(10). 
1 Assistant Secretary of Defense for Research and Engineering Attn: Committee on Sciences Pentagon Building Washington $25, \mathrm{D}$. $G$ 。

2 Office of Naval Research Geophysics Branch (Code 476) Washington 25, D。C.

4 Chief of Naval Research Washington $25, \mathrm{D}$ 。C。

Attn: Code 446 (1) Biology Branch 463 (1) Surface Branch 466 (I) Undersea Warfare Branch

418 (1) Special Projects

1 Commanding Officer Office of Naval Research Branch 495 Summer Street

Boston 10, Massachusetts

1 Commanding Officer Office of Naval Research Branch 346 Broadway New York 13, New York

1 Commanding Officer Office of Naval Research Branch The John Crerar Library Building 86 East Randolph Street Chicago 1 , Illinois

1 Commanding Officer Office of Naval Research Branch 1000 Geary Street San Francisco 9, California

1 Commanding Officer Office of Naval Research Branch 1030 East Green Street Pasadena 1, California

\section{Commanding Officer} Office of Naval Research Branch Navy \#100, Fleet Post Office New York, New York
1 Contract Administrator Southeastern Area

Office of Naval Research

2110 G Street, N。W.

Washington 7, D. C.

- I Office of Naval Research Resident Representative University of Washington Seattle 5, Washington.

6 Director

Naval Research Laboratory Attn: Technical Services Information Officer

Washington 25 , D. C.

8 U. S. Navy Hydrographic Office Attn: Division of Oceanography Washington 25, D. C.

4 Chief, Bureau of Ships Navy Department Washington $25, \mathrm{D} . \mathrm{C}$.

Attn: Code 312 (I)
320 (1)
631 (I)
698 (1)

3 Chief, Bureau of Aeronautics Navy Department Washington 25, D。C.

$$
\begin{array}{ll}
\text { Attn: } & \mathrm{PH}-41 \text { (1) } \\
& \mathrm{AY}-3 \text { (I) } \\
\mathrm{AV}-433 \text { (1) }
\end{array}
$$

1 Chief of Naval Operations Navy Department Washington $25, \mathrm{D}$. C :

Attn: $0 p-58$

1 Chief, Bureau of Yards and Docks Navy Department Washington 25, D. C. 
1 Oceanographic Institute Florida State University Tallahassee, Florida

1 Director, Marine Laboratory University of Miami

\#1 Rickenbacker Causeway

Virginia Key

Miami 49, Florida

I Head, Department of Oceanography

Texas A \& M College

College Station, Texas

1 Director

Scripps Institution of Oceanography

La Jolia, California

I Alian Hancock Foundation

University Park

Los Angeles 7, Callfornia

1 Department of Engineering University of California

Berkeley, California

1 Dr。 Wayne Vo Burt

Oregon State College

Corvallis, Oregon

$I$ Head, Department of Oceanography

University of Washington

Seattle 5 , Washington

1 Director

Hawaii Marine Laboratory

University of Hawail

Honolulu, Hawail

1 Director

Arctic Research Laboratory

Box 1070

Fairbanks, Alaska

1. Geophysical Institute of the University of Alaska

College, Alaska

1 Director

Bermuda Biological Station for Research

St. George's

Bermuda, Bo Wo I。
1 Chief, Ocean Research

U. S. Fish and Wildlife Service

450 B. Jordan Hall

Stanford, California 
2 Chief, U. So Weather Bureau $2400 \mathrm{M}$ Street, NoW。 Washington $25, \mathrm{~B}, \mathrm{C}$.

Attn: Dr. Ho Wexler

2 Director, U. So Fish and Wildlife Service

Department of Interior

Bureau of Commercial Fisheries

Washington $25, \mathrm{D}$ 。 $\mathrm{C}$ 。

1 U. So Fish \& Wildlife Service

Woods Hole, Maseachusetts

3 U. S. Fish \& Wildlife Service

Pacific Oceanic Fishery Investigation

P. 0. Box 3830

HonoluIu, Hawaii ..

Attr: Librarian (1)

$$
\text { T. So Austin (1) }
$$

I U. S. Fish \& Wildlife Service Scripps Institution of Oceanography La Jolla, Caiifornia

\section{Director}

Woods Hole Oceanographic Institution Woods Hole, Massachusetts

2 Project Officer Laboratory of Oceanography

Woods Hole, Massachusetts

1 Director Narragansett Marine Laboratory Kingston, Rhode Island

1 Bingham Oceanographic Laboratories Yale University

New Haven, Connecticut

1 Chairman

Dept. of Meteorology \& Oceanography

New York University

New York 53, New York

1 Director

Iamont Geological Observatory

Torrey Cliff

Palisades, New York
1 Director

Hudson Laboratories

Columbia University

145 Palisades Street

Dobbs Ferry, New York

I Department of Conservation

Cornell University

Ithaca, New York

Attn: Dr。 JoC. Ayers

1 Dr。 F。 B。 Berger

- General Precision Laboratory

Pieasantville, New York
I Dr. I。 Goldmuntz

Technical Research Group

56 West 45th Street

New York 36, New York

I Dr. Harold Haskins

Rutgers University

New Brunswick, New Jersey

1 Director, Chesapeake Bay Institute Johns Hopkins University

I2I Maryland $\mathrm{Hall}$

Baltimore 18, Maryland

1 Mail No. H-3071

The Martin Company

Baltimore 3, Maryland

Attn: Hydrodynamics-Geophysics Staff

1 Dr。C.I。 Beard

Sylvania Electric Defense Lab.

P. 0. Box 205

Mt。 View, California

1 Director

Applied Physics Laboratory

8621 Georgia Avenue

Silver Springs, Maryland

1 Mr. Henry D. Simmons, Chief

Estuaries Section

Waterways Experiment Station

Corps of Engineers

Vicksburg, Mississippi 
3 Commanding Officer \& Director U. S. Navy Electronics Laboratory San Diego 52, California

Attn: 2230

1 Commanding Officer \& Director U. S。 Naval Civil Engineering Laboratory

Port Hueneme, California

Attn: Code $\mathrm{L} 54$

1 Cormander Naval Ordnance Laboratory, White Oak Silver Springs 19, Maryland

1 Commanding Officer

U. S. Navy Mine Countermeasure Station

Panama City, Florida

1 officer in Charge

U. S. Navy Weather Research Facility

U., S. Naval Air Station

Building $R-48$

Norfolk, Virginia

1 Commanding officer

U. S. Navy Air Development Center Johnsville, Pennsylvania

1 Superintendent

U. S. Naval Academy

Annapolis, Maryland

2 Department of Meteorology and Oceanography

U. S. Naval Post Graduate School

Monterey, California

1 Director of Research \& Development

Office, Deputy Chief of Staff, Development

Hdqtrs。, U.S $\circ$ A $\circ$.

Washington $25, \mathrm{D}$ 。C。

I Chief, Air Weather Service

Department of the Air Force

Scott Field, Illinois
I Commanding Officer

Geophysics Research

Directorate

Hansc om Field

Bedford, Massachusetts

1 Chief of Research and Development

Department of the Army

Attn: Army Research Office

Washington $25, \mathrm{D}$ 。C.

1 Chief, Armed Forces Special Weapons Project

P. 0. Box 2610

Washington 25, D。C.

1 U. S. Army Beach Erosion Board 5201 Iittle Falls Road N. W. Washington 16, D。C。

I U. S. Waterways Experiment Station Vicksburg, Mississippi

1 Office of Technical Services Department of Commerce Washington $25, \mathrm{D}$. C.

5 Armed Services Technical Information Center

Documents Section Arlington Hall Arlington 12, Virginia

2 National Research Council 2101 Constitution Avenue Washington $25, \mathrm{D}$. C 。

\section{Attn: Committee on Undersea Warfare Committee on Oceanography}

1 Commandant (OAO)

U. S. Coast Guard

Washington $25, \mathrm{D} . \mathrm{C}$.

1 Director

U. S. Coast \& Geodetic Survey Division of Tides and Currents Department of Commerce Washington $25, \mathrm{D}$ 。C. 